\title{
Hubungan Pengetahuan Ibu terhadap Interprestasi Hasil KPSP Anak
}

\section{Usia 0-24 Bulan}

\author{
Sagita Darma Sari, Wera Astriani \\ Email: sagitaDarmaSari98@gmail.com \\ STIKES Abdurahman Palembang \\ Jl. Sukajaya No. 7, Kol. H. Burlian KM 5,5 Palembang
}

Telp/ Fax (0711) 421674

\begin{abstract}
Abstrak
Masa bayi dan balita merupakan masa yang penting dalam pertumbuhan dan perkembangan anak. Sangat penting bagi orang tua untuk mengetahui perkembangan anak sebagai dasar untuk mengetahui perkembangan selanjutnya. Tujuan penelitian ini adalah untuk mengetahui hubungan pengetahuan ibu terhadap interprestasi hasil KPSP anak usia 0-24 bulan di Bpm Sagita Darma Sari Palembang. Desain penelitian ini deskriftif kuantitatif dengan pendekatan cross sectionaldengan sampel 88 responden yang dipilih secara purposive sampling. Pengumpulan data dengan kuesioner dan diolah dengan uji rank spearman. Hasil penelitian ini menunjukan terdapat hubungan yang signifikan antara pengetahuan ibu dengan interprestasi hasil KPSP anak usia 0-24 bulan yang nilai $\rho$ value $=0,000$ lebih kecil dari $\alpha 0,05$ ( $\rho$ value $\leq \alpha)$. Peneliti merekomendasikan tenaga kesehatan khususnya di Bpm Sagita Darma Sari Palembang agar lebih meningkatkan deteksi dini tumbuh kembang anak, sehingga apabila terjadi keterlambatan perkembangan anak dapat mengambil langkah-langkah pencegahan lebih awal.
\end{abstract}

Kata Kunci: pengetahuan; KPSP; tumbuh kembang.

\begin{abstract}
The period of infancy and toddler is an important period in the growth and development of children. It is very important for parents to know the child's developments as a basis for knowing further developments. The purpose of this study was to determine the relationship of maternal knowledge on the interpretation of the results of KPSP children aged 0-24 months at BPM Sagita Darma Sari Palembang. The design of this research is quantitative descriptive with cross sectional approach with a sample of 88 respondents selected by purposive sampling. Data collection by questionnaire and processed by Spearman rank test. The results of this study indicate that there is a significant relationship between mother's knowledge and KPSP interpretation of children aged 024 months whose $\mathrm{p}$ value $=0,000$ is smaller than a 0.05 ( $\mathrm{p} \mathrm{va)}$. Researchers recommend that health workers, especially at BPM Sagita Darma Sari Palembang to further enhance the early detection of child growth and development, so that if there is a delay in the development of children can take precautionary steps earlier.
\end{abstract}

Keywords: knowledge; KPSP; child development.

\section{Pendahuluan}

$\begin{array}{ll}\text { Usia } & 0-24 \text { bulan merupakan } \\ \text { masa } & \text { pertumbuhan dan }\end{array}$
perkembangan yang pesat, sehingga dikatakan sebagai periode emas sekaligus periode kritis. Periode emas dapat diwujudkan apabila pada masa ini bayi dan anak memperoleh asupan gizi yang sesuai untuk tumbuh kembang optimal. Sebaliknya apabila bayi dan anak pada masa ini tidak memperoleh makanan sesuai kebutuhan gizinya, maka periode emas akan berubah menjadi periode kritis yang akan mengganggu tumbuh kembang bayi 
Jurnal Kebidanan Harapan Ibu Pekalongan

dan anak, baik pada saat ini maupun masa selanjutnya ${ }^{[1]}$.

Masa bayi dan balita merupakan masa yang penting dalam pertumbuhan dan perkembangan anak. Maka dalam memberikan asuhan yang bermutu tinggi dan komperehensif pada bayi dan balita, sangat penting bagi orang tua untuk mengetahui perkembangan bayi dan balita sebagai dasar untuk mengetahui perkembangan selanjutnya, yaitu pra sekolah, sekolah, akil balik dan remaja.Untuk perkembangan balita yang baik, dibutuhkan kesehatan dan gizi yang baik dari ibu hamil, bayi, dan anak pra-sekolah. Stimulasi atau rangsangan yang cukup dalam kuantitas dan kualitas sejak awal juga dibutuhkan bayi dan anak untuk perkembangan mental dan psikososialnya ${ }^{[2]}$. Oleh karena itu, orang tua khususnya ibu harus memiliki pengetahuan tentang proses pertumbuhan dan perkembangan pada anak usia pra sekolah sehingga bila ada kelainan tumbuh kembang secara dini bisa diketahui ${ }^{[3]}$.

Dalam proses pertumbuhan dan perkembangan orang tua berperan penting terutama ibu untuk mengetahui dan membina anak dalam proses tumbuh kembangnya agar tumbuh kembang anak dapat menjadi optimal. Dalam hal ini pemberian informasi sangat dibutuhkan dari seorang tenaga kesehatan.Tenaga kesehatan dapat memberikan informasi tentang pemberian stimulasi dan kecapaian perkembangan yang dialami masa prasekolah. Dengan pemberian informasi diharapkan dapat mengubah sikap dalam pemberian stimulasi terutama pada masa prasekolah ${ }^{[4]}$.

Salah satu upaya meningkatkan pertumbuhan dan perkembangan bayi adalah dengan pemberian ASI Eksklusif. Di awal hidupnya, bayi membutuhkan nutrisi adekuat untuk tumbuh kembangnya. Air Susu Ibu merupakan faktor lingkungan biologis dan kebutuhan asuh yang mengandung nutrisi terbaik bagi bayi karena ASI mengandung semua zat gizi dengan jumlah dan komposisi yang ideal serta sifat ASI yang sangat mudah diserap oleh tubuh bayi. Kandungan laktosa, lemak, protein, garam dan mineral, vitamin, lisozim, antibody dan sel darah putih pada ASI sangat bermanfaat untuk membantu pertumbuhan dan perkembangan bayi yang optimal serta melindungi terhadap berbagai penyakit. Selain pemberian ASI secara eksklusif, salah satuupaya meningkatkan perkembangan bayi adalah stimulasi psikososial merupakan faktor lingkungan psikososial dan kebutuhan asah untuk menunjang perkembangan bayi dimana stimulasi psikososial adalah cikal bakal proses pembelajaran anak melalui pendidikan dan pelatihan dalam bentuk aktivitas bermain. Melalui stimulasi psikososial, anak dapat mengendalikan dan mengkoordinasikan otot - ototnya serta melibatkan perasaan emosi dan pikiran sehingga anak mendapat berbagai pengalaman hidup. Pemberian stimulasi akan lebih efektif apabila memperhatikan kebutuhan anak sesuai dengan tahap perkembangannya ${ }^{[3]}$.

Stimulasi mendorong lebih dari 200 juta anak di seluruh dunia mengoptimalkan potensi perkembangannya. Anak yang menerima stimulasi secara terarah akan lebih cepat berkembang dibandingkan anak yang kurang atau tidak mendapatkan stimulasi. Stimulasi dapat dilakukan oleh orang tua, anggota keluarga, petugas kesehatan, atau orang dewasa lain di sekitar anak ${ }^{[5]}$. Gangguan perkembangan apabila tidak terdeteksi atau ditangani dengan baik akan mengurangi kualitas sumber daya manusia di masa yang akan datang. Kuesioner Pra Skrining Perkembangan (KPSP) merupakan salah satu dari metode deteksi atau skrining terhadap 
Jurnal Kebidanan Harapan Ibu Pekalongan

kelainan perkembangan anak. Anggapan bahwa skrining merupakan hal yang membebani, menyita waktu, sulit dipahami, serta validitas dan reliabilitas instrumen masih rendah membuat pelaksanaan skrining belum maksimal di layanan kesehatan primer $^{[3]}$.

Orang tua terutama ibu diharapkan memberikan stimulasi dini dengan memberikan sentuhan, katakata, dan tatapan untuk mengoptimalkan tumbuh kembang anak selanjutnya. Stimulasi yang dilakukan oleh ibu merupakan stimulasi terbaik.Ibu dengan pengetahuan yang baik dapat berpengaruh terhadap sikap dan perilaku dalam melakukan stimulasi perkembangan anak secara bertahap, berkelanjutan, dan menyeluruh terhadap semua aspek perkembangan anak $^{[5]}$. Berdasarkan hasil penelitian dari wawancara anak saat melakukan DDST oleh Herlina (2010), sebagian besar anak yang memiliki perkembangan diduga mengalami kegagalan dalam sektor personal sosial dan motorik halus dikarenakan orang tua yang jarang bahkan tidak pernah mengajari anaknya. Mereka cenderung membiarkan anaknya berkembang apa adanya, bahkan jarang berinteraksi dan memberikan stimulasi kepada anaknya dikarenakan kesibukan orang tua.

Menurut penelitian yang dilakukan Sudirman dkk (2016), Ada hubungan antara tingkat pengetahuan ibu dengan tahap pencapaian pertumbuhan dan perkembangan balita. Ibu yang memiliki tingkat pengetahuan baik maka tahap pertumbuhan dan perkembangan balita memiliki pertumbuhan yang baik dan mencapai tahap perkembangan yang sesuai dengan tahapan umur. Oleh karena itu baik ibu ataupun petugas kesehatan hendaknya selalu bekerjasama untuk melakukan deteksi dini penyimpangan pertumbuhan dan perkembangan balita agar dapat dilakukan intervensi dini bila balita mengalami masalah tumbuh kembang.

Pertumbuhan adalah perubahan dalam besar, jumlah, ukuran, atau dimensi tingkat sel, organ, maupun individu yang bisa diukur dengan ukuran berat (gram, pon, kilogram), ukuran panjang (cm, meter), umur tulang, dan keseimbangan metabolik ( retensi kalsium dan nitrogen tubuh).Pertumbuhan mempunyai dampak terhadap aspek fisik, sedangkan perkembangan berkaitan dengan pematangan fungsi organ/individu. Berat badan merupakan gambaran dari masa tubuh, massa tubuh sangat peka dalam waktu yang singkat. Perubahan tersebut secara langsung tergantung oleh adanya penyakit infeksi dan nafsu makan. Pada anak yang mempunyai status kesehatan dan nafsu makan yang baik, maka pertambahan berat badan akan mengikuti sesuai dengan usianya. Akan tetapi, apabila anak mempunyai status kesehatan yang tidak baik maka pertumbuhan akan terhambat. Oleh karena itu berat badan mempunyai sifat labil dan digunakan sebagai salah satu indikator status gizi yang menggambarkan keadaan saat ini. Tinggi badan memberikan gambaran tentang pertumbuhan. Pada keadaan tubuh yang normal, pertumbuhan tinggi badan bersamaan dengan usia. Pertumbuhan tinggi badan berlangsung lambat, kurang peka pada kekurangan zat gizi dalam waktu yang singkat.Dampak pada tinggi badan akibat kekurangan zat gizi belangsung sangat lama, sehingga dapat menggambarkan keadaan gizi masa lalu. Keadaan tinggi badan pada usia sekolah menggambarkan status gizi berdasarkan indeks TB/U saat baduta $^{[6]}$.

Perkembangan (development) adalah perubahan yang bersifat kuantitatif dan kualitatif, yaitu 
Jurnal Kebidanan Harapan Ibu Pekalongan

bertambahnya kemampuan (skill) struktur dan fungsi tubuh yang lebih kompleks.Termasuk didalamnya perkembangan kognitif, bahasa, motorik, emosi, dan perkembangan prilaku $^{[3]}$.

\section{Metode Penelitian}

Penelitian ini menggunakan penelitian deskriptifkuantitatif dengan pendekatan potong lintang (cross sectional).Populasi pada penelitian ini adalah seluruh bayi berusia 0-24 bulan dan teknik sampel yang digunakan adalah Purposive Sampling dengan memenuhi karakteristik inklusi dan eklusi, adapun variabel yang digunakan dalam penelitian ini yaituvariabel independent dalam penelitian ini pengetahuan ibu terhadap tumbuh kembang anak dan Variabel hasil interprestasi KPSP. Teknik pengumpulan data pada penelitian ini menggunakan data primer dimana peneliti akan menggunakan sampel yang langsung ditemukan pada saat penelitian, setelah didapatkan sampel maka peneliti akan mengajukan pertanyaan menggunakan Kuesioner Pra Skrining Perkembangan (KPSP). Uji statistik pada penelitian ini menggunakan metode rank spearman. Dengan tingkat kemaknaan $(\alpha) 0,05$ jika $\rho$ value $\leq 0,05$ bearti ada hubungan antara variabel dependen dengan variabel independen.

\section{Hasil dan Pembahasan}

\section{Karakteristik Responden}

\section{a. Umur Ibu}

Tabel 1. Distribusi frekuensi umur ibu di BPM Sagita Darma Sari Palembang Tahun 2020

\begin{tabular}{ccc}
\hline Umur & Frekuensi (n) & Presentase (\%) \\
\hline$<20$ tahun & 2 & 2,3 \\
$20-35$ tahun & 86 & 97,7 \\
\hline Jumlah & 88 & 100
\end{tabular}

Berdasarkan tabel 1, dapat dilihat bahwa dari 88 responden diketahui bahwa umur ibu $<20$ tahun sebanyak 2 responden $(2,3 \%)$ sedangkan umur ibu 20-35 tahun sebanyak 86 responden $(97,7 \%)$.

\section{b. Umur Bayi}

Tabel 2. Distribusi frekuensi umur bayi di BPM Sagita Darma Sari Palembang Tahun 2020

\begin{tabular}{ccc}
\hline Umur bayi & Frekuensi (n) & Presentase (\%) \\
\hline 1-12 bulan & 58 & 65,9 \\
$13-24$ bulan & 30 & 34,1 \\
\hline Jumlah & 88 & 100 \\
\hline
\end{tabular}

Berdasarkan tabel 2, dapat dilihat bahwa dari 88 responden diketahui bahwa umur bayi 1-12 bulan sebanyak 58 responden $(65,9 \%)$ sedangkan umur bayi 13-24 bulan sebanyak 30 responden $(34,1 \%)$.

\section{c. Jenis kelamin bayi}

Tabel 3. Distribusi frekuensi jenis kelamin bayi di BPM Sagita Darma Sari Palembang Tahun 2020

\begin{tabular}{ccc}
\hline $\begin{array}{c}\text { Jenis } \\
\text { kelamin }\end{array}$ & Frekuensi (n) & Presentase (\%) \\
\hline Laki-laki & 35 & 39,8 \\
Perempuan & 53 & 60,2 \\
\hline Jumlah & 88 & 100 \\
\hline
\end{tabular}

Berdasarkan tabel 3, dapat dilihat bahwa dari 88 responden diketahui bahwa bayi berjenis kelamin laki-laki sebanyak 35 responden $(39,8 \%)$ sedangkan perempuan sebanyak 53 responden $(60,2 \%)$. 
Jurnal Kebidanan Harapan Ibu Pekalongan

\section{d. Tingkat Pengetahuan ibu}

Tabel 4. Distribusi frekuensi tingkat pengetahuan ibu terhadap interprestasi hasil KPSP anak usia 0-24 bulan di BPM Sagita Darma Sari Palembang

\begin{tabular}{ccc}
\hline $\begin{array}{c}\text { Tingkat } \\
\text { Pengetahuan }\end{array}$ & $\begin{array}{c}\text { Frekuensi } \\
\text { (n) }\end{array}$ & $\begin{array}{c}\text { Presentase } \\
\text { (\%) }\end{array}$ \\
\hline Baik $>75-100$ & 41 & 46,6 \\
Cukup 65-75 & 27 & 30,7 \\
Kurang $<65$ & 20 & 22,7 \\
\hline Jumlah & 88 & 100 \\
\hline
\end{tabular}

Berdasarkan tabel 4, dari 88 responden diketahui bahwa tingkat pengetahuan ibu baik sebanyak 41responden $(46,6 \%)$ pengetahun ibu cukup 27 responden (30,7\%) pengetahuan ibu kurang sebanyak 20 responden $(20,7 \%)$.

Pengetahuan merupakan hasil dari penggunaan pancaindera yang didasarkan atas intuisi atau kebetulan,otoritas dan kewibawaan,tradisi dan pendapat umum. Sehingga Orang tua terutama ibu diharapkan dapat memberikan stimulasi dini dengan memberikan sentuhan, kata-kata, dan tatapan untuk mengoptimalkan tumbuh kembang anak selanjutnya.Stimulasi yang dilakukan oleh ibu merupakan stimulasi terbaik ${ }^{[7]}$.

Hasil penelitian ini sejalan dengan penelitan Kurniawati dan Hanifah, bahwa pengetahuan ibu tentang stimulasi tumbuh kembang dalam kategori baik sebanyak 18 responden $(60 \%)$ dan pengetahuan ibu tentang stimulasi tumbuh kembang dalam kategori cukup sebanyak 8 responden $(26,7 \%)$ sedangkan pengetahuan ibu tentang stimulasi tumbuh kembang dalam kategori kurang sebanyak 4 responden $(13,3 \%)^{[8]}$.

Oleh karena itu pengetahuan ibu disini sangat penting dalam memberikan stimulus yang benar bagi perkembangan balita.Seorang anak memerlukan perhatian khusus untuk optimalisasi tumbuh kembangnya. Optimalisasi perkembangan diperlukan adanya interaksi antara anak dan orangtua, terutama peranan ibu sangat bermanfaat bagi proses perkembangan anak secara keseluruhan karena orangtua dapat segera mengenali kelainan proses perkembangan anaknya sedini mungkin dan memberikan stimulus tumbuh kembang anak yang menyeluruh dalam aspek fisik, mental, dan sosial.

\section{e. Hasil interprestasi KPSP}

Tabel 5. Distribusi frekuensi hasil interprestasi KPSP anak usia 0-24 bulan di BPM Sagita Darma Sari Palembang

\begin{tabular}{ccc}
\hline Hasil KPSP & Frekuensi (n) & Presentase (\%) \\
\hline $\begin{array}{c}\text { Sesuai (9-10) } \\
\text { Meragukan } \\
(7-8)\end{array}$ & 78 & 88,6 \\
& 10 & 11,4 \\
\hline Jumlah & & 100
\end{tabular}

Berdasarkan tabel 5, dapat dilihat bahwa dari 88 responden diketahui bahwa hasil interprestasi KPSP sesuai (9-10) sebanyak 78 responden $(88,6 \%)$ sedangkan meragukan (7-8) sebanyak 10 responden $(11,4 \%)$.

Perkembangan (development) adalah perubahan yang bersifat kuantitatif dan kualitatif, yaitu bertambahnya kemampuan (skill) struktur dan fungsi tubuh yang lebih kompleks. Termasuk didalamnya perkembangan kognitif, bahasa, motorik, emosi, dan perkembangan prilaku (Soetjiningsih, 2014).Umur yang paling rawan adalah masa balita, oleh karena pada masa itu anak mudah sakit dan mudah terjadi kurang gizi.Disamping itu masa balita merupakan dasar pembentukan kepribadian anak sehingga diperlukan perhatian khusus.

Terdapat empat faktor risiko yang mempengaruhi perkembangan anak- 
Jurnal Kebidanan Harapan Ibu Pekalongan

anak di negara berkembang yaitu malnutrisi kronis berat, stimulasi dini yang tidak adekuat, defisiensi yodium dan anemia defisiensi besi.Salah satu faktor resiko yang penting dan berhubungan dengan interaksi ibu dan anak adalah pemberian stimulasi dini.Ibu dengan pengetahuan yang baik dapat berpengaruh terhadap sikap dan perilaku dalam melakukan stimulasi perkembangan anak secara bertahap,

\section{f. Hubungan Pengetahuan Ibu Terhadap Interprestasi KPSP Anak Usia 0-24 Bulan}

Tabel 6. Hubungan pengetahuan ibu terhadaptumbuh kembangdengan hasilinterprestasi KPSP anak usia 0-24 bulan diBPM Sagita Darma Sari Palembang

\begin{tabular}{|c|c|c|c|c|c|c|c|c|}
\hline \multirow[t]{3}{*}{ Pengetahuan } & \multicolumn{4}{|c|}{ Hasil interprestasi KPSP } & \multirow{2}{*}{\multicolumn{2}{|c|}{ Total }} & \multirow[t]{3}{*}{$\rho$ value } & \multirow[t]{3}{*}{$\rho_{x y}$} \\
\hline & \multicolumn{2}{|c|}{ S (Sesuai) } & \multicolumn{2}{|c|}{ M (Meragukan) } & & & & \\
\hline & N & $\%$ & $\mathrm{~N}$ & $\%$ & $\mathrm{~N}$ & $\%$ & & \\
\hline Baik & 41 & 100 & 0 & 0 & 41 & 100 & \multirow{4}{*}{0,000} & \multirow{4}{*}{0,466} \\
\hline Cukup & 25 & 92,6 & 2 & 7,4 & 27 & 100 & & \\
\hline Kurang & 12 & 60 & 8 & 40 & 20 & 100 & & \\
\hline Total & 78 & 88,6 & 10 & 11,4 & 88 & 100 & & \\
\hline
\end{tabular}

Berdasarkan tabel 6, dapat dilihat bahwa dari 88 responden ibu berdasarkan tingkat pengetahuan didapatkan bahwa dari 41 orang yang tingkat pengetahuannya baik terdapat 41 orang $(100 \%)$ yang hasil interprestasi KPSP nya sesuai dan $0 \%$ yang hasil interprestasi KPSP nya meragukan dan dari 27 orang yang tingkat pengetahuannya cukup terdapat 25 orang $(92,6 \%)$ hasil interprestasi KPSP nya sesuai dan 2 orang $(7,4 \%)$ hasil interprestasi KPSP nya meragukan sedangkan dari 20 orang yang tingkat pengetahuannya kurang terdapat 12 orang $(60 \%)$ hasil interprestasi KPSP nya sesuai dan 8 orang $(11,4 \%)$ hasil interprestasi KPSP nya meragukan.

Berdasarkan uji statistik rank spearman didapatkan bahwa nilai $\rho_{\mathrm{xy}}$ adalah sebesar 0,466 dan $\rho$ value $=0,000$ lebih kecil dari $\alpha 0,05$ ( $\rho$ value $\leq \alpha)$. berkelanjutan, dan menyeluruh terhadap semua aspek perkembangan anak ${ }^{[9]}$.Hal ini sejalan dengan hasil penelitian Kurniawati dan Hanifah di peroleh bahwa pengetahuan ibu baik dan cukup dapat mempengaruhi sikap dan perilaku ibu dalam memberikan stimulasi pada balitanya ${ }^{[8]}$.
Hal ini menunjukkan bahwa terdapat hubungan yang signifikan antara tingkat pengetahuan ibu terhadap hasil interpretasi KPSP dengan tingkat hubungan yang sedang karena $\rho_{\mathrm{xy}}$ berada pada interval koefisien 0,40 0,599 (Sugiyono, 2008) dan mempunyai arah korelasi yang positif, sehingga semakin tinggi tingkat pengetahuan ibu tentang tumbuh kembang maka semakin baik hasil interpretasi KPSP nya.

Hal ini sejalan dengan penelitian Kurniawati dan Hanifah, dikemukakan bahwa terdapat hubungan antara pengetahuan ibu tentang stimulasi tumbuh kembang dengan perkembangan balita usia 12-36 bulan di Posyandu Kasih Ibu 7 Banyu Urip Klego Boyolali Tahun 2014. Hal ini ditunjukkan dengan tingginya presentase ibu dengan tingkat pengetahuan yang baik sebanyak 18 responden $(60 \%)$ dan yang 
perkembangan balita nya sesuai sebanyak 22 responden $(73,3 \% \%)^{[8]}$.

Hal ini sesuai dengan teori Notoadmodjo, pengetahuan atau kognitif merupakan domain yang sangat penting untuk terbentuknya tindakan seseorang (ovent behavior). Dari pengalaman dan penelitian ternyata perilaku yang didasari oleh pengetahuan akan lebih langgeng daripada perilaku yang tidak didasari oleh pengetahuan ${ }^{[7]}$.

Salah satu faktor yang mempengaruhi pengetahuan adalah umur, responden dalam penelitian ini sebagian besar 86 responden $(97,7 \%)$ berusia antara 20-35 tahun, yaitu berada pada usia reproduktif. Usia 20-35 tahun pada wanita merupakan usia reproduktif dan berada pada usia melahirkan yang dianjurkan. Usia reproduktif sangat berpengaruh terhadap pengetahuan tentang perkembangan anak dan praktek-praktek pengasuhan anak. Semakin cukup umur, tingkat kematangan dan kekuatan seseorang akan lebih matang dalam berfikir dan bekerja $^{[10]}$.

Kemampuan orang tua dalam memberikan stimulasi kepada balita dapat dilihat dari pengetahuan yang baik dalam memberikan stimulasi perkembangan kepada balita. Kemampuan ibu dapat dilihat dari peningkatan pengetahuan, sikap, dan perilaku dalam menstimulus balita.Orang tua terutama ibu diharapkan memberikan stimulasi dini dengan memberikan sentuhan, katakata, dan tatapan untuk mengoptimalkan tumbuh kembang anak selanjutnya.Stimulasi yang dilakukan oleh ibu merupakan stimulasi terbaik.Ibu dengan pengetahuan yang baik dapat berpengaruh terhadap sikap dan perilaku dalam melakukan stimulasi perkembangan anak secara bertahap, berkelanjutan, dan menyeluruh terhadap semua aspek perkembangan anak ${ }^{[9]}$.

\section{Kesimpulan}

Dapat disimpulkan bahwa Distribusi frekuensi berdasarkan tingkat pengetahuan ibu baik sebanyak 41 responden $(46,6 \%)$, pengetahuan ibu cukup sebanyak 27 responden $(30,7 \%)$ sedangkan pengetahuan ibu kurang sebanyak 20 responden $(22,7 \%)$. Serta untuk Distribusi frekuensi berdasarkan hasil interprestasi KPSP sesuai (9-10) sebanyak 78 responden $(88,6 \%)$ sedangkan meragukan (7-8) sebanyak 10 responden (11,4\%). Sehingga terdapat hubungan yang cukup dan signifikan pengetahuan ibu terhadap tumbuh kembang denganhasil interprestasi KPSP anak usia 0-24 bulan dengan nilai $\rho$ value $0,000 \geq 0,05$ yang artinya $\mathrm{H}_{\mathrm{a}}$ diterima dan $\mathrm{H}_{0}$ ditolak.

\section{Daftar Pustaka}

[1] Nutrisiani, Pertumbuhan dan Perkembangan Anak, Jakarta: Salemba Medika, 2010.

[2] Maryunani, Pengenalan Praktis MTBS (Manajemen Terpadu Balita Sakit) Untuk Paramedis, Bogor: In Media, 2014.

[3] Soetjiningsih, Ranuh,Tumbuh Kembang Anak, Jakarta: EGC, 2014.

[4] Chamida, Pertumbuhan dan Perkembangan Anak, Jakarta: Rineka Cipta, 2013.

[5] Palasari, W., Purnomo, D., Keterampilan Ibu Dalam Deteksi Dini Tumbuh Kembang Terhadap Tumbuh Kembang Bayi, Jurnal STIKES, 5(1), pp.11-20, 2012. 
Jurnal Kebidanan Harapan Ibu Pekalongan

[6] Aritonang, I., Model Multilevel Pertumbuhan Anak Usia 0-24 Bulan dengan Variabel yang Mempengaruhinya. Jurnal Penelitian dan Evaluasi Pendidikan. Politeknik Kesehatan Kemenkes Yogyakarta, 130-142. 2013.

[7] Notoadmojo, S.,Ilmu Perilaku Kesehatan. Jakarta: Rineka Cipta, 2011.

[8] Kurniawati, A., Hanifah, L.,Hubungan Pengetahuan ibu tentang Stimulasi Tumbuh Kembang Balita Usia 12-36 Bulan di Posyandu Kasih Ibu 7 Banyu urip Klego Boyolalu Tahun 2014,Jurnal Kebidanan Indonesia, Vol 6(1) 83-100, 2014.

[9] Santrock, JW.,Life, Span Develoment, Perkembangan Masa Hidup. Jakarta: Erlangga, 2011.

[10] Deki, Factors Affecting Early Childhood Growth and Develoment: Golden 1000 Days. Advanced Practices In Nursing 1(01) 1-4, 2016. 